\title{
Analisis Faktor yang Berhubungan dengan Minat Akseptor KB Menggunakan Alat Kontrasepsi Dalam Rahim (AKDR) di Desa Keude Panga Kabupten Aceh Jaya
}

\author{
Analysis of Factors Related to Interest in KB Acceptors Using Intrauterin \\ Device in The Village of Keudeu Panga Aceh Jaya
}

\author{
Nuzulul Rahmi* ${ }^{* 1}$ Melda Andriani², Asmaul Husna ${ }^{3}$ \\ 1,2 Program Studi D-III Kebidanan, Fakultas Ilmu Kesehatan, Universitas Ubudiyah Indonesia, Banda Aceh, Indonesia \\ ${ }^{3}$ Program Studi D-III Kebidanan, Fakultas Ilmu Kesehatan, Universitas Ubudiyah Indonesia, Banda Aceh, Indonesia \\ *Korespondensi Penulis: nuzulul_r@uui.ac.id
}

\begin{abstract}
Abstrak
Pemilihan metode kontrasepsi AKDR/IUD khususnya di Indonesia selama beberapa tahun terakhir cenderung mengalami penurunan peminat. Faktor-faktor tersebut antara lain: faktor fisik, psikologis, sosial budaya dan agama, tingkat pendidikan, pengetahuan, lingkungan, ekonomi, kebutuhan, tarif pelayanan, dan dukungan suami/keluarga. Tujuan Penelitian ini ntuk menganalisis faktor-faktor yang berhubungan dengan minat akseptor KB Menggunakan AKDR Di Desa Keude Panga Kecamatan Panga Tahun 2017. Penelitian ini bersifat analitik, dengan pendekatan cross sectional, populasi dalam penelitian ini adalah seluruh akseptor KB Di Desa Keude Panga Kecamatan Panga yang berjumlah 175 orang. Tehnik pengambilan sampel dilakukan dengan caraquota sampling, jumlah sampel yang didapat 35 orang. Pengumpulan data dilakukan pada tanggal 13 Mei s/d 26 Mai 2017. Analisa data dilakukan dengan menggunakan Uji Chi-Square dengan batas kemaknaan 95\% (P<0,05). Hasil penelitian menunjukkanada hubungan antara tingkat pengetahuan ibu dengan minat akseptor $\mathrm{KB}$ dalam menggunakan $\mathrm{AKDR}$ dengan nilai $\mathrm{P}=0,027$, ada hubungan antara tingkat ekonomi keluarga dengan minat akseptor KB dalam menggunakan AKDR dengan nilai $\mathrm{P}=0,001$. ada hubungan antara dukungan suami dengan minat akseptor $\mathrm{KB}$ dalam menggunakan AKDR dengan nilai $\mathrm{P}=0,007$, ada hubungan antara sosial budaya dengan minat akseptor $\mathrm{KB}$ dalam menggunakan $A K D R$ dengan nilai $\mathrm{P}=0,009$. Kesimpulan pada penelitian ini ada hubungan yang bermakna antara pengetahuan, tingkat ekonomi keluarga, dukungan suami dan sosial budaya dengan minat akseptor KB menggunakan AKDR.
\end{abstract}

Kata kunci : Alat kontrasepsi dalam rahim, IUD, Akseptor KB

\section{Abstract}

The choice of IUD / IUD contraceptive methods especially in Indonesia over the past few years tends to decrease in interest. These factors include: physical, psychological, sociocultural and religious factors, education level, knowledge, environment, economy, needs, service rates, and husband / family support. The purpose of this study was to analyze the factors associated with interest in family planning acceptors using IUDs in Keude Panga 
Village, Panga District, 2017. This study was analytical, with a cross sectional approach, the population in this study were all family planning acceptors in Keude Panga Village, Panga District. 175 people. The sampling technique was done by quota sampling, the number of samples obtained was 35 people. Data collection was carried out on May 13 to 26 May 2017. Data analysis was performed using the Chi-Square Test with a significance limit of $95 \%(P$ $<0.05)$. The results showed that there was a relationship between the level of knowledge of mothers and interests of family planning acceptors in using the IUD with a value of $P=$ 0.027 , there was a relationship between the family economic level and the interest of family planning acceptors in using an IUD with a $P$ value of 0.001. there is a relationship between husband's support and the interest of family planning acceptors in using the IUD with a $P$ value of 0.007, there is a relationship between socio-cultural and the interests of family planning acceptors in using the IUD with a P value $=0.009$. The conclusion of this study is that there is a significant relationship between knowledge, family economic level, husband support and socio-culture with the interest of family planning acceptors using an IUD.

Keywords: Intrauterine device, IUD, Acceptor KB

\section{PENDAHULUAN}

Indonesia merupakan sebuah negara berkembang dengan jumlah peningkatan penduduk yang tinggi, dengan laju pertumbuhan sebesar 1,49 persen per tahun. Pertumbuhan penduduk ini tentu saja berimplikasi secara signifikan terhadap perkembangan ekonomi dan kesejahteraan Negara (Irianto, 2014). Menurut Murdaningsih (2014), Indonesia juga sebagai salah satu negara berkembang, tidak luput dari masalah kependudukan. Secara garis besar masalah-masalah pokok di bidang kependudukan yang dihadapi Indonesia adalah: jumlah penduduk yang besar dengan laju pertumbuhan penduduk yang relatif masih tinggi, persebaran penduduk yang tidak merata, stuktur umur muda, dan kualitas penduduk yang masih harus ditingkatkan.

Menurut data Program Pelayanan Kesehatan Dinas Kesehatan Aceh, tahun 2015 jumlah PUS di Provinsi Aceh 107,667 orang. Peserta KB Aktif yang menggunakan metode kontrasepsi IUD 5.3\%. Di Aceh Jaya jumlah PUS 1612 orang Peserta KB yang menggunakan metode kontrasepsi IUD 34 orang (2,1\%). Di Desa Keude Panga Kecamatan Panga akseptor KB aktif berjumlah 175 jiwa. Penggunaan alat kontrasepsi yang dijumpai memakai suntikan 102 orang $(58,4 \%)$, memakai pil 35 orang (20\%), memakai implant 8 orang $(4,6 \%)$, memakai kondom 20 orang $(11,4 \%)$, yang menggunakan MOW 1 orang $(0,5 \%)$, yang menggunakan KB alami 8 orang $(4,6 \%)$ dan yang memakai AKDR 1 org (0,5\%) (Data Pos KB Desa Panga, 2016).Berdasarkan data yang didapatkan peneliti bahwa angka pemakaian KB AKDR hanya 1 orang di Desa Panga sehingga peneliti sangat tertarik untuk meneliti hal ini. 


\section{METODE PENELITIAN}

Jenis penelitian ini bersifat Survey Analitik dengan desain cross sectional. populasi dalam penelitian ini adalah keseluruhan objek penelitian yang diteliti yaitu seluruh akseptor KB di Desa Keude Panga Kecamatan Panga yang berjumlah 175 orang, peneliti mengambil sampel 20\% dari populasi yang berjumlah 175 orang, jadi banyaknya sampel adalah 35 orang yang dilakukan pada tanggal 13 Mei sampai dengan 26 Mei 2017 yang dibantu dengan enumerator. Data diolah dengan uji Chi-Square dan menggunakan komputerisasi dengan Ci (Confident Interval) 95\%.

\section{HASIL DAN PEMBAHASAN}

Tabel 1. Distribusi Frekuensi Analisis faktor-faktor yang berhubungan dengan minat akseptor KB menggunakan AKDR di Desa Keude Panga Kecamatan Panga

\begin{tabular}{|c|c|c|c|}
\hline No. & Variabel & Frekuensi & $\%$ \\
\hline 1. & $\begin{array}{l}\text { Minat Akseptor KB Menggunakan AKDR } \\
\text { a. Berminat } \\
\text { b. Tidak Berminat }\end{array}$ & $\begin{array}{l}24 \\
11\end{array}$ & $\begin{array}{l}68,6 \\
31,4\end{array}$ \\
\hline 2. & $\begin{array}{l}\text { Pengetahuan Ibu } \\
\text { a. Baik } \\
\text { b. Cukup } \\
\text { c. Kurang }\end{array}$ & $\begin{array}{c}13 \\
17 \\
5\end{array}$ & $\begin{array}{l}37,1 \\
48,6 \\
14,3\end{array}$ \\
\hline 3. & $\begin{array}{l}\text { Tingkat Ekonomi Keluarga } \\
\text { a. }<\text { UMP } \\
\text { b. } \geq \text { UMP }\end{array}$ & $\begin{array}{l}16 \\
19\end{array}$ & $\begin{array}{l}45,7 \\
54,3\end{array}$ \\
\hline 4. & $\begin{array}{l}\text { Dukungan Suami } \\
\text { a. Mendukung } \\
\text { b. Tidak mendukung }\end{array}$ & $\begin{array}{l}22 \\
13\end{array}$ & $\begin{array}{l}62,9 \\
37,1\end{array}$ \\
\hline 5. & $\begin{array}{l}\text { Sosial Budaya } \\
\text { a. Mendukung } \\
\text { b. Tidak mendukung }\end{array}$ & $\begin{array}{l}15 \\
20\end{array}$ & $\begin{array}{l}42,9 \\
57,1\end{array}$ \\
\hline
\end{tabular}

Dari tabel 1 dapat dilihat bahwa ibu yang berminat menggunakan KB AKDR lebih banyak daripada yang tidak berminta yaitu 68,6\%. Pengetahuan ibu lebih banyak pada katagori cukup yaitu 48,6 \% dibandingkan pengetahuan yang baik dan kurang. Tingkat ekonomi keluarga lebih banyak pada tingkat pendapatan lebih besar dari UMP yaitu 54,3\% dibandingkan dengan pendapatan dibawah UMP. Suami yang mendukung menggunakan KB lebih banyak yaitu 62,9\% dibandingkan suami yang tidak mendukung. Sosial budaya yang tidak mendukung menggunakan KB lebih banyak yaitu 57,1\% dibandingkan dengan sosial budaya yang mendukung. 
Tabel 2. Analisis Faktor-faktor yang Berhubungan dengan Minat Akseptor KB Menggunakan AKDR di Desa Keude Panga Kecamatan Panga

\begin{tabular}{|c|c|c|c|c|c|c|c|c|}
\hline \multirow{2}{*}{ No } & \multirow{2}{*}{$\begin{array}{c}\text { Variabel } \\
\text { Independen }\end{array}$} & \multirow{2}{*}{ Katagori } & \multicolumn{3}{|c|}{$\begin{array}{c}\text { Minat akseptor KB } \\
\text { menggunakan AKDR }\end{array}$} & \multirow[b]{2}{*}{$\mathrm{f}$} & \multirow{2}{*}{ Total } & \multirow{2}{*}{$\begin{array}{c}P \\
\text { Value }\end{array}$} \\
\hline & & & Berminat & f & $\begin{array}{c}\text { Tidak } \\
\text { berminat }\end{array}$ & & & \\
\hline \multirow{2}{*}{1.} & \multirow{2}{*}{ Pengetahuan } & Baik & 12 & 92,3 & 1 & 7,7 & 13 & \multirow{2}{*}{0,027} \\
\hline & & Cukup & 12 & 54,5 & 10 & 45,5 & 22 & \\
\hline \multirow{2}{*}{2.} & \multirow{2}{*}{$\begin{array}{l}\text { Tingkat } \\
\text { ekonomi }\end{array}$} & $\geq$ UMP & 18 & 94,7 & 1 & 5,3 & 19 & \multirow{2}{*}{0,001} \\
\hline & & $<\mathrm{UMP}$ & 6 & 37,5 & 10 & 62,5 & 16 & \\
\hline \multirow[b]{2}{*}{3.} & \multirow{2}{*}{$\begin{array}{l}\text { Dukungan } \\
\text { suami }\end{array}$} & Mendukung & 19 & 86,4 & 3 & 13,6 & 22 & \multirow[b]{2}{*}{0,007} \\
\hline & & $\begin{array}{l}\text { Tidak } \\
\text { mendukung }\end{array}$ & 5 & 38,5 & 8 & 61,5 & 13 & \\
\hline \multirow[b]{2}{*}{4.} & \multirow[b]{2}{*}{ Sosial budaya } & Mendukung & 14 & 93,3 & 1 & 6,7 & 15 & \multirow[b]{2}{*}{0.009} \\
\hline & & $\begin{array}{l}\text { Tidak } \\
\text { mendukung }\end{array}$ & 10 & 50 & 10 & 50 & 20 & \\
\hline
\end{tabular}

\section{Pembahasan}

1. Hubungan Pengetahuan Ibu Dengan Minat Akseptor KB Menggunakan AKDR

Berdasarkan hasil penelitian yang telah dilakukan oleh peneliti menunjukkan bahwa dari 13 akseptor KB yang berpengetahuan baik yang berminat menggunakan AKDR ada sebanyak 92,3\%, serta dari 22 akseptor KB yang berpengetahuan cukup yang berminat menggunakan AKDR ada 54,5\%. Dari hasil uji statistik (Chi-Square) diperoleh nilai $\mathrm{P}$ value 0,027 sehingga dapat disimpulkanterdapat hubungan antara tingkat pengetahuan ibu dengan minat akseptor KB dalam menggunakan AKDR.

Menurut penelitian Destyowati tahun 2011 dengan judul hubungan tingkat pengetahuan ibu tentang kontrasepsi IUD dengan minat pemakaian kontrasepsi IUD di Desa Harjobinangun Kecamatan Grabak Kabupaten Purworejo dengan jenis penelitian analitik dengan pendekatan survey dengan jumlah sampel 47 responden dengan hasil ada hubungan tingkat pengetahuan ibu tentang kontrasepsi IUD dengan minat pemakaian kontrasepsi IUD.

Hal ini sesuai dengan pendapat Jawiriah (2009) bahwa pengetahuan seseorang dalam memilih alat kontrasepsi sangat menentukan PUS dalam ber-KB, jika pengetahuan tentang KB sudah mantap, maka dalam memilih alat kontrasepsi dapat dilakukan dengan tepat dan mudah. Jika pengetahuannya tentang KB masih kurang, maka dalam pemilihan dan pelaksanaannya merupakan suatu kendala dalam ber-KB. 
Pengetahuan merupakan hasil tahu dan ini terjadi setelah orang melakukan penginderaan terhadap suatu objek tertentu. Penginderaan terjadi melalui panca indra manusia yakni: indra penglihatan, pendengaran, penciuman, rasa dan raba. Sebagian besar pengetahuan manusia diperoleh melalui mata dan telinga. Sebagian besar pengetahuan diperoleh melalui pendidikan, pengalaman diri sendiri maupun orang lain, media massa, serta lingkungan. Pengetahuan atau kognitif merupakan domain sangat penting untuk terbentuknya tindakan seseorang (Notoatmodjo, 2012).

Berdasarkan asumsi peneliti bahwa pengetahuan seseorang mempengaruhi minat akan pemilihan alat kontrasepsi. Jika pengetahuannya baik, maka ibu telah mengerti manfaat, efek samping serta kontra indikasi untuk alat kontrasepsi termasuk AKDR sehingga akan memilih kontrasepsi yang cocok untuk dirinya dan tidak berbahaya bagi kesehatannya jika dipakai untuk jangka panjang seperti kontrasepsi AKDR.

2. Hubungan Tingkat Ekonomi Keluarga dengan Minat Akseptor KB Menggunakan AKDR

Berdasarkan hasil penelitian yang telah dilakukan oleh peneliti menunjukkan bahwa dari 16 akseptor dengan tingkat ekonomi <UMP ada 62,5\% yang tidak berminat menggunakan AKDR, serta dari 19 akseptor dengan tingkat ekonomi $\geq \mathrm{UMP}$ ada 5,3\% saja yang tidak berminat menggunakan AKDR. Dari hasil uji statistik (Chi-Square) diperoleh $\mathrm{P}$ value 0,001 artinya ada pengaruh antara tingkat ekonomi keluarga dengan rendahnya minat akseptor KB menggunakan AKDR.

Menurut penelitian yang dilakukan oleh Marikar tahun 2015 dengan judul Faktor faktor yang berhubungan dengan minat ibu terhadap penggunaan alat kontrasepsi dalam rahim (AKDR) di Puskesmas Tuminting Kota Manado dengan desain penelitian cross sectional dengan jumlah sampel 84 responden dengan ekonomi dengan penggunaan AKDR.

Hal ini sesuai dengan pendapat yang dinyatakan oleh BKKBN (2014) bahwa penghasilan/pendapatan seseorang sangat berpengaruh terhadap pemilihan alat kontrasepsi. Ini disebabkan oleh mahalnya alat kontrasepsi yang ingin digunakan dalam ber KB dan juga biaya untuk menuju tempat pelayanan kesehatan karena letak geografis yang jauh, sehingga ibu memilih alat kontrasepsi yang agak murah padahal alat kontrasepsi tersebut tidak sesuai untuk mereka gunakan. Kondisi lemahnya ekonomi 
keluarga mempengaruhi daya beli termasuk kemampuan membeli obat dan alat kontrasepsi IUD.

Berdasarkan asumsi peneliti, kehidupan seseorang sangat ditunjang oleh kemampuan ekonomi keluarga sehingga jika sebuah keluarga berada pada ekonomi yang rendah atau penghasilan dibawah UMP akan sangat sulit untuk memenuhi kebutuhan dalam upaya meningkatkan pelayanan kesehatan pada keluarga. Upaya peningkatan kesehatan salah satunya adalah dengan cara menjarangkan kehamilan dengan menggunakan alat kontrasepsi. Jika keluarga berpenghasilan <UMP maka akan sulit untuk memenuhi daya beli pemasangan AKDR sehingga minat untuk pemakaian alat kontrasepsi ini menjadi kurang.

3. Hubungan Dukungan Suami dengan Minat Akseptor KB Menggunakan AKDR

Berdasarkan hasil penelitian yang telah dilakukan oleh peneliti menunjukkan bahwa dari 22 akseptor KB dengan suami mendukung menggunakan AKDR ada sebanyak 86,4\% yang berminat menggunakan AKDR, serta dari 13 akseptor KB yang tidak mempunyai dukungan suami menggunakan AKDR ada 38,5\% yang berminat menggunakan AKDR. Dari hasil uji statistik (Chi-Square) diperoleh P value 0,007artinya ada hubungan antara dukungan suami dengan rendahnya minat akseptor $\mathrm{KB}$ menggunakan AKDR.

Berdasarkan hasil penelitian yang dilakukan oleh Sulastri dan Nirmasari tahun 2014 dengan judul penelitian Hubungan dukungan suami dengan minat ibu dalam pemakaian kontrasepsi IUD Di Puskesmas Bergas Kabupaten Semarang menggunakan desain deskriptif korelasi dengan pendekatan cross sectional dengan jumlah sampel 89 responden didaptkan hasil ada hubungan bermakna antara dukungan suami dengan minat ibu dalam pemakaian kontrasepsi IUD.

Hasil penelitian ini sesuai dengan pendapat yang dinyatakan oleh Fatimah (2013) bahwa keberhasilan program Keluarga Berencana tidak terlepas dari peran dan partisipasi suami dalam mendukung ataupun berperan aktif menggunakan alat atau cara kontrasepsi dalam keluarga. Berbagai peran aktif dapat memberikan kontribusi dalam program adalah partisipasi dalam keluarga berencana dan juga dukungan kepada keluarga atau istri. Program KB dapat terwujud dengan baik apabila terdapat dukungan dari pihak-pihak tertentu. Ikatan suami istri yang kuat sangat membantu ketika keluarga menghadapi 
masalah, karena suami/istri sangat membutuhkan dukungan dari pasangannya. Dukungan tersebut akan tercipta apabila hubungan interpersonal keduanya baik. Masyarakat di Indonesia khususnya di daerah pedesaan, sebagai peran penentu dalam pengambilan keputusan dalam keluarga adalah suami sedangkan istri hanya bersifat memberikan sumbang saran. Metode kontrasepsi tidak dapat dipakai istri tanpa kerjasama suami dan saling percaya. Keadaan ideal bahwa pasangan suami istri harus bersama memilih metode kontrasepsi yang terbaik, saling kerjasama dalam pemakaian, membiayai pengeluaran akan kontrasepsi, dan memperhatikan tanda bahaya pemakaian.

Kesetaraan dan keadilan gender merupakan suatu kondisi yang sejajar dan seimbang secara harmonis dalam hubungan kerjasama antara laki-laki dan perempuan, karena tidak adanya perlakuan deskriminatif antara laki-laki dan perempuan. Kesetaraan dan keadilan gender dalam $\mathrm{KB}$ dan kesehatan reproduksi merupakan suatu kondisi yang seimbang antara suami dan istri dalam akses, partisipasi dan manfaat pelayanan serta posisi setara dalam pengambilan keputusan mengenai $\mathrm{KB}$ dan kesehatan reproduksi (BKKBN, 2014).

Berdasarkan asumsi peneliti, dukungan suami terhadap pemakaian AKDRakan sangat mempengaruhi istri untuk memiliki minat menggunakan AKDR. Hal ini dikarenakan di Provinsi Aceh masih sangat menghargai hak suami dalam pengambilan keputusan sehingga seorang istri harus meminta izin kepada suaminya jika ingin memilih alat kb. Jika suami tidak mendukung pemakaian AKDR maka istri tidak berminat untuk menggunakannya.

4. Hubungan Sosial Budaya dengan Minat Akseptor KB Menggunakan AKDR

Berdasarkan hasil penelitian yang telah dilakukan oleh peneliti menunjukkan bahwa dari 15 akseptor dengan sosial budayanya mendukung ada 93,3\% yang berminat menggunakan AKDR, serta dari 20 akseptor yang tidak mempunyai dukungan sosial budaya ada sebanyak 50\% yang berminat menggunakan AKDR. Dari hasil uji statistik (Chi-Square) diperoleh $\mathrm{P}$ value 0,009 , artinya ada hubungan antara sosial budaya dengan rendahnya minat akseptor KB menggunakan AKDR.

Menurut hasil penelitian yang dilakukan oleh Bernadus, dkk tahun 2013 dengan judul Faktor factor yang berhubungan dengan pemilihan alat kontrasepsi dalam rahim (AKDR) bagi akseptor KB di Puskesmas Jailolo dimana jenis penelitiannya 
analitikdengan rancangan cross sectionaldengan jumlah sampel 96 responden. Hasil penelitian menunjukkan bahwa ada hubungan budaya dengan pemilihan AKDR.

Penelitian Murdaningsih tahun 2014 yang berjudul faktor-faktor yang berhubungan dengan rendahnya penggunaan kontrasepsi Intra Uterine Device (IUD) pada Wanita Usia Subur (WUS) di Desa Sidomukti Kecamatan Bandungan Kabupaten Semarang, juga didapatkan hasil penelitian yang menunjukkan bahwa ada hubungan antara sosial budaya pasangan wanita usia subur dengan rendahnya penggunaan kontrasepsi IUD di Desa Sidomukti Kecamatan Bandungan Kabupaten Semarang.

Hasil penelitian ini sesuai dengan pendapat yang dinyatakan oleh Aritonang (2010) yang menyatakan bahwa penggunaan alat kontrasepsi juga turut dipengaruhi oleh factorsosial budaya mengingat penggunanya hidup dalam lingkungan sosial budaya. Penggunaan alat kontrasepsi sangat terkait dengan budaya, sebab alat kontrasepsi terkait dengan cara pemasangan dan kebiasaan masyarakat pada umumnya mengikuti kebudayaan dan adat-istiadat yang sejak dulu telah dibentuk demi mempertahankan hidup dirinya sendiri ataupun kelangsungan hidup suku mereka. Untuk tercapainya keberhasilan suatu program pembangunan khususnya dalam masyarakat ini perlu dipahami apa yang terdapat dan diadatkan dalam masyarakat.

Aritonang (2010) juga menyatakan bahwa sebagai makhluk sosial manusia hidup tidak terlepas dari budaya bahkan dapat dipengaruhi oleh budaya dimana ia hidup. Budaya menyangkut adat istiadat, tradisi kebiasaan, aturan-aturan dan pendapat-pendapat. Penggunaan alat kontrasepsi sangat terkait dengan budaya, karena alat kontrasepsi terkait dengan cara pemasangan dan kebiasaan menggunakan. Sebagaimana diketahui bahwa pemasangan alat kontrasepsi IUD misalnya, pemasangan alat ini melalui alat kemaluan wanita yang tidak terterima pada orang-orang dilingkungan budaya tertentu. Di samping itu penggunaannya terkait dengan kebiasaan masyarakat yang hidup dilingkungan tertentu. Seseorang akan tertarik menggunakan salah satu alat kontrasepsi jika orang-orang disekitarnya menggunakan alat kontrasepsi yang sama. Contohnya ketertarikan seseorang pada penggunaan alat kontrasepsi suntik akan timbul jika orang-orang disekitarnya juga menggunakan kontrasepsi suntik. Termasuk juga kebiasaan yang turun temurun, dari ibu ke anak, dan seterusnya. Dalam hal ini perlu melibatkan para tokoh agama dan tokoh masyarakat dalam melakukan penyuluhan tentang penggunaan metode kontrasepsi di masyarakat. Misalnya dengan mengajak ulama atau kepala desa yang istrinya telah 
menggunakan alat kontrasepsi sehingga dapat menjadi referensi dan panutan masyarakat dalam menggunakan alat kontrasepsi.

Berdasarkan asumsi peneliti, terdapat hubungan antara sosial budaya dengan minat akseptor $\mathrm{KB}$ menggunakan $\mathrm{AKDR}$, hal ini disebabkan semakin tinggi dukungan sosial budaya setempat dengan pemakaian alat kontrasepsi AKDR maka akan mempengaruhi minat ibu dalam menggunakan alat kontrasepsi. Apalagi jika tetangga, keluarga dan orang tuanya dahulu juga memakai alat kontrasepsi ini, akan menambah minat ibu untuk memilih kontrasepsi ini.

\section{KESIMPULAN}

Kesimpulan penelitian ini ada hubungan yang bermakna antara pengetahuan ibu dengan nilai $\mathrm{P}=0,027$, tingkat ekonomi nilai $\mathrm{P}=0,001$, dukungan suami nilai $\mathrm{P}=0,007$, sosial budaya nilai $\mathrm{P}=0,009$ dengan minat akseptor KB menggunakan AKDR di Desa Keude Panga kecamatan Panga.

\section{SARAN}

Diharapkan kepada petugas kesehatan untuk dapat memberikan informasi lebih mengenai alat kontrasepsi khususnya tentang kontrasepsi dalam rahim. Diharapkan kepada peneliti selanjutnya agar melakukan penelitian lanjutan dengan metode dan variabel yang lebih kompleks tentang alat kontrasepsi dalam rahim.

\section{DAFTAR PUSTAKA}

Depkes. (2012). Profil Kesehatan Reproduksi Indonesia. WHO; Jakarta.

Destyowati, Mitha. (2011). Hubungan Tingkat Pengetahuan Ibu Tentang Kontrasepsi IUD Dengan Minat Pemakaian Kontrasepsi IUD Di Desa Harjobinangun Kecamatan Grabak Kabupaten Purworejo. Jurnal komunikasi kesehatan edisi 5 : Jawa Tengah

Dinkes. (2016). Profil Kesehatan Provinsi Aceh 2015.http://www.dinkes.acehprov.go.id (dikutip tanggal 25 Maret 2017)

Meilani, dkk. (2010). Pelayanan Keluarga Berencana. Fitramaya : Yogyakarta

Murdaningsih. (2014). Faktor-Faktor Yang Berhubungan Dengan Rendahnya Penggunaan Kontrasepsi Intra Uterine Device (Iud) Pada Wanita Usia Subur (Wus) Di Desasidomukti Kecamatan Bandungan Kabupaten Semarang. perpusnwu.web.id/karyailmiah/documents/3528.pdf (dikutip tanggal 10 Maret 2017)

Notoatmodjo S. (2012). Pendidikan Dan perilaku Kesehatan. Rineka Cipta; Jakarta. 